\title{
On Excavating the Paleocinema of Cebu: An Interview with Misha Boris Anissimov and Paul Douglas Grant
}

Teddy Co

\section{April 1987}

My discovery of Cebuano cinema began when I was working with my colleague, film historian and filmmaker Nick Deocampo, at the MOWELFUND Film Institute. Nick had launched a film magazine called Movement and asked me to contribute a piece on any subject concerning Philippine cinema. I was then involved in research at the institute and managed to acquire for its library bound sets of movie magazines published from 1935 to 1940, which I bought from pioneer movie publicist and later movie producer Luis F. Nolasco, who founded and edited some of the publications. The magazines bore names like LiterarySong-Movie, Philippine Movies and Radio, and Popular Movie News. The last was edited by journalist, fictionist, poet, and later screenwriter and film critic, T.D. Agcaoili, and in its September 1940 issue carried an article on early Cebuano attempts to set up a film industry in the province.

Serendipitously, I discovered that the in-house photographer of MOWELFUND, Luis Chiong, had worked as a cinematographer during the fledgling days of the Cebuano film scene, from the late 1930s until the '50s. Chiong, then 67 years old, gave me a fascinating account of the beginnings of the film industry in Cebu. The information he shared with me eventually formed part of the article I contributed to Movement magazine entitled, "In Search of Philippine Regional Cinema" (1987), which gives a historical 
overview of regional filmmaking in the country and delves into the concept "regional cinema" as a paradigm for speaking of Philippine cinema.

\section{November 1990}

At MOWELFUND again. This time Nick asked me to join him in programming the Quezon City International Super-8 Film Festival, which was to be held at the 500-seat Wave Cinema in Cubao, the country's first theater established expressly to show movies shot on video, put up by SONY Philippines. A year earlier, I was able to locate an independent movie made by producer-brothers Domingo and Narciso Arong in Cebu. The Arong brothers became legendary in the late 1970s, when they shot a full-length movie using Super-8 film stocks, had the negatives processed, and had their edited reels blown up to $35 \mathrm{~mm}$ at a film laboratory in San Francisco, California. The movie, Ang Manok ni San Pedro (1977), was eventually screened in town fiestas at public plazas, became a big hit, and earned a small fortune for the brothers. It made history for being the first film to be blown up from Super- 8 to $35 \mathrm{~mm}$ in the annals of world cinema. Unfortunately, its coming also signaled the demise of the Cebuano movie industry.

Domingo Arong had sent me the original Super-8 copy of Manok by courier. The film was already brittle and many of its frames were scratched and discolored when we received it. Even in its sad state, however, we went ahead and screened it as the closing highlight of the Quezon City International Super-8 Film Festival, to a sparse but enthusiastic crowd of mostly independent filmmakers. We managed to invite Manok's director, Jose Macachor, after learning that he had an office in Manila; he was then chairman of the Games and Amusements Board. Macachor showed up at the screening but did not say much, other than that, since he had some experience in doing radio dramas, he was asked by the Arongs to direct the film.

\section{February 2005}

Flash forward to 2005. Nick was organizing the Pelikula at Lipunan Film Festival, which at this time already had several editions held in Metro Manila. This time, however, the festival was to be held in Cebu. Filmmakers Eddie Romero, Peque Gallaga, Kidlat Tahimik, and Kiri Dalena were invited to give talks. The festival was to be a tribute of sorts to Cebuano cinema, and some of Cebu's surviving film veterans were present - director and producer Gene Labella, cinematographer Luis Chiong, actress Caridad Sanchez, and the Arong brothers. 
Ang Manok ni San Pedro, with the original faded and scratchy print that Domingo Arong had sent to us at MOWELFUND over a decade earlier, was shown again to a near-empty theater at SM Cebu. The surprise hit of the festival was the Cesar Montano-acted-and-directed Panaghoy sa Suba (2004). Shot in Bohol, the movie's dialogue was completely in Cebuano; it was the first feature-length film with dialogue in the Visayan language since Eh, Kasi Bisaya (1992), which was produced in Manila a dozen years earlier.

During the festival's opening ceremonies, I finally met Narciso Arong, coproducer of the legendary Ang Manok ni San Pedro. And since Kidlat Tahimik was also present, I introduced them to each other. Manok and Perfumed Nightmare were both released in 1977, during a period that is remembered as Philippine cinema's Golden Age. The founding father of indie filmmaking from up north and the last filmmaker to have shot on celluloid in the south faced each other and firmly shook hands. Sadly, there were no smartphone cameras then to record this magnificent selfie moment and only my testimony will attest that the two had actually met.

\section{July 2012}

In 2012, Misha Boris Anissimov and Paul Douglas Grant, two Americans who had just established a pioneering film program at the University of San Carlos in Cebu, arranged to meet with me at the MOWELFUND. Both timed their trip to Manila to coincide with the 8th Cinemalaya Film Festival. Misha and Paul wanted to view Manok and another earlier Cebuano film, Badlis sa Kinabuhi (1969), which starred Gloria Sevilla and her late husband Mat Ranillo, Jr.

Badlis was directed by Leroy Salvador. It created a stir in the movie scene in the late 1960s, when it was shown in Manila and received several nominations at the FAMAS awards, including for Best Picture and Best Actress, which Sevilla won. The film was also screened at the Berlin Film Festival. Sevilla left the badly deteriorated master negatives of Badlis at MOWELFUND some years earlier, and film archivist Ricky Orellana and Nick Deocampo tried to get the film restored at a film laboratory in Australia, with dismal results. Many parts, especially at the film's beginning, had dirt and splotches already embedded on the celluloid, and a fourth of the soundtrack was gone. The film's sequences were also jumbled up, since the original reels were not kept in proper order.

In spite of Manok's and Badlis's bad state, Misha and Paul were impressed enough by what Ricky had shown them and thought that they could make something out of these damaged copies. Like paleontologists who had just 
discovered ancient bones, they asked for digital version of the films so that they could take them back to Cebu and continue to probe them.

Both Misha and Paul are zealous but sophisticated film connoisseurs, whose knowledge of world cinema range from Soviet classics to Hong Kong martial arts epics to French New Wave and militant documentaries. They are also familiar with the better-known Filipino auteurs like Lino Brocka and Ishmael Bernal, whose films were accessible to them in the U.S. When they relocated to $\mathrm{Cebu}$, however, they developed a more specific and sustained mission: to research, retrieve, and recover the lost heritage of Cebuano cinema.

\section{March 30, 2015}

In 2015, Misha and Paul invited me over to the Talamban campus of the University of San Carlos, for the commencement exercises of the school's first ever batch of film students. As the keynote speaker, I gave a rambling account of my "discovery" of and engagement with Cebuano cinema, mentioning the many films by Cebuano filmmakers that I helped, as a script reader for Cinema One Originals since 2009, push into production. One such film was Ang Damgo ni Eleuteria (2010), the one-take wonder which was directed by Remton Siega Zuasola and voted Best Picture at the Urian awards of 2011. Since then, the names of Keith Deligero, Christian Linaban, Victor Villanueva, and Ara Chawdhury have been added to the burgeoning list of Cebuano auteurs.

The day after graduation, I was at the campus office of Misha and Paul, wondering what they did with the DVD of Badlis that Ricky and I gave them at MOWELFUND three years earlier. They had done major surgery on the film, and, while the result was far from perfect technically, what they showed me was nothing short of magical. The story's sequences were now in proper order, and it had subtitles in English allowing the viewer to understand even the soundless dialogue spoken by the movie characters in the parts that had no sound track. To do the trick, Misha and Paul hired a local to read the lips of the characters. Badlis sa Kinubuhi was now watchable again. Misha, this time, graciously handed me a digital file of the film.

\section{August 6, 2015}

In 2015, I programmed the "new" Badlis sa Kinabuhi as the opening film of Cinema Rehiyon 7 Film Festival at SM Cebu. Cinema Rehiyon is a flagship program of the National Commission for Culture and the Arts (NCCA). Many of the viewers who watched Badlis, especially the Cebuanos, stayed on to finish the two-hour long film and were enraptured by the emotional 
power of the film's old-fashioned melodrama. At some point, the audience of young people was singing along with the film.

The producer and star of Badlis, no other than the "Queen of Visayan Movies” herself, Gloria Sevilla, graced the screening. This was the film's first public showing in over three decades. After the screening, Misha and Paul went up the stage to greet and talk with Sevilla, for the first time. One year later, Lilas: An Illustrated History of the Golden Ages of Cebuano Cinema (2016), authored by Misha and Paul, is published, the first book on the history of Cebuano cinema. On the cover of the handsome book are Mat Ranillo, Jr. and Gloria Sevilla, stars of Badlis sa Kinabuhi.

\section{April 6, 2016}

In responding to my query on how two American film scholars ended up living in Cebu with their respective families and got seriously engaged with the Cebuano film scene, I got this email reply from Paul:

I received a contract to do a book on Filipino cinema, and we [with Paul's wife and kids] were living in France, in the countryside, which was beautiful but needed something a bit more in the world. The research possibilities matched with my love for Filipino cinema are the reasons (back in 2001 I was already trying to figure out how to come here to the Philippines and teach in some capacity - that was the time we were going with friends to Jackson Heights in Queens and rummaging through the dusty boxes of old VHS tapes in the Filipino video rental shops). So it means the lucrative was less an inspiration for me than the rich culture.

Misha had changed his career from an HVA engineer to going to film school. He met and married a Cebuana [pen pal] and was living in San Francisco when they decided to come to live in Cebu. Upon his arrival he found there was a film scene but not any real formal training so he approached USC about the film school. Also he set up screenings of his collections of DVDs, which was titled the Tioseco-Bohinc Film Archives. ${ }^{1}$ (Grant, 2016, personal communication)

The rest of the interview I did with Misha and Paul, which follows this short introduction, sheds more light on these cinephiles' love affair with Cebuano cinema. 
TEDDY CO (TC): What got you both interested in researching Cebuano cinema, when Filipino film experts have all but ignored it all these years, except in a few rare cases?

MISHA BORIS ANISSIMOV (MBA): I stumbled into it. My wife is from Cebu, and in 2009 we decided to move here. Being a curious enthusiast of film history, I discovered all sorts of on-line writing on this peculiar "lost" Cebuano cinema. I read all I could find but quickly realized that the information out there was poorly organized and inadequately researched. In 2010, I pitched the idea of teaching film to then Dean Maxwell Espina at the University of San Carlos. He immediately tasked me with crafting a new BFA Cinema program at the University of San Carlos. After that program got going, I pitched the idea of a researchbased Master of Arts in Cinema Studies program, after the American and European model. Paul Douglas Grant became our first full-fledged film professor. I felt that the program could be a vehicle for creating scholars who will focus on Cebuano and regional film research as well as creating a home-grown pool of film professors. Nick Deocampo's monograph on Lost Cebuano Cinema was a revelation and the starting point for our research. The University of San Carlos Cebuano Studies Center had a copy. It was fascinating, but it was just a beginning.

PAUL DOUGLAS GRANT (PDG): I had always been interested in Filipino cinema in general. In New York, we used to go from Brooklyn over to Jackson Heights, Queens, to raid the VHS boxes at the newly minted DVD stores. We found plenty of unsubtitled Brocka, bomba, and even some Lav Diaz stuff like Serafin Geronimo: Kriminal $n g$ Barrio Concepcion (1998). This stuff was not easy to come by, and there was no decent history of Filipino cinema published in the States or Europe. So in some ways the national cinema was already a kind of minor cinema in my eyes, quite simply because it hadn't been mined abroad ad infinitum. That kind of little known cinema is what I've always gone after. In French cinema, I wrote a book about the very minor militant cinemas of the 1970s. So when coming to the Philippines and discovering that there is this cinema that struggled against Tagalog language cinemas as early as the late 1930s, it was of course something that immediately had me interested.

TC: Aside from the absence of copies of films, since the bulk of Cebuano films are lost, what were the biggest obstacles that you faced in excavating data and information on Cebuano cinema?

MBA: For me, the vernacular language barrier and the seductive qualities of published misinformation. These two items, coupled with missing 
films, result in a slow-down in research time, which then becomes another challenge. Progress becomes slow. Aside from Nick Deocampo's monograph, and some writing by Resil Mojares and Erlinda Alburo, the vast majority of information in the periodicals of the period leaned heavily on gossip and star culture. Besides missing the films, it was rare to even find synopsis of story lines, or film writing in general. Film writing, rooted in original references, was almost non-existent. By its very nature, these gossip columns and occasional recollections of past history were rooted in stories based on fuzzy recollections, selective memory, and repetition of hearsay. We were put in the position of a type of "backwards research," in that a historically significant claim would be made in a magazine, about this or that, and we would be tasked to prove or disprove it.

PDG: The lack of films is a problem for a few reasons. The first is that we can't do traditional film analysis, or sequence analysis, or even try to figure out the various genre and how they work trans-generically as well. So aesthetically and technically we're left in the dark. But then the other major problem is quite simply verifying the existence of these films. That means that we are bound to periodicals and theater schedules to corroborate film titles and dates. And in many ways the schedules became our most trusted ally because many titles are mentioned in Bisaya, Bag-ong Suga and other local periodicals, which are said to be in production or about to be released, and then we never see them listed or talked about in the past tense. The other issue is that of self-staging, where the boundary between journalist and publicist is not always so clear and articles that seem to be critically assessing a film or singing its praises often come from the production itself. There is also self-staging in interviews, wherein people foreground their own experience in a way that might not be compatible with the narrative that we trace out in the ephemera of the archives. Although this was less a problem with interviewees than it was with newspapers and other periodicals.

TC: What were your most useful tools in doing research? And how would you advise future researchers on how to go about gathering information about a "lost" or forgotten cinema, when extant films and published information are both scant?

PDG: We are extremely fortunate that the university we work at, University of San Carlos, is also home to the Cebuano Studies Center (CSC), which houses a massive amount of Cebuano periodicals in English, Spanish, and Bisaya. Without CSC, we wouldn't have been able to undertake a book project so quickly. The center's director Hope Yu was 
very accommodating and we were allowed full access, so it wasn't like researching in, say, the BnF [Bibliothèque nationale de France], where you basically go in once, get all you can, and hope that it was enough. With the access and proximity, we were able to go back all we needed in order to verify or re-photograph or sift through piles of uncatalogued periodicals, pamphlets and other ephemera. Finding things like the serialization of a film in comic or prose form felt like we had found a long lost film. We even dug up old screenplays for Cebuano films in the CSC. Now, having said that, journalism, and in particular entertainment journalism as it appears in those periodicals, is often as bombastic as a self-staging interviewee, meaning our empirical ground zero for a film's existence was the movie schedule that showed the days and times of the screening. But that doesn't mean the bombast is useless. It is actually quite telling and helps us get a sense of the tenor of the age, or the cultural desire to see Cebuano cinema take it's rightful place on the stage of Philippine national cinema.

MBA: We were lucky. The Cebuano Studies Center has a remarkable periodicals collection dating back to the early 1900s with issues of BagOng Kusog. We were also fortunate that a good deal of the publications were published in English. The unfortunate part is that factually referenced scholarly Cebuano film writing was almost non-existent. We were starting from scratch. It's a tough mountain to climb, but our discoveries and insights were quite exciting. I think in the future we need to work on a variation of a research methodology called "data triangulation," but adapted to a Filipino-interview context. We can call it "interview data triangulation." There is a lot of information stored in the brains of Filipinos who were first-person witnesses to historical film events, and a methodology designed to verify pertinent information from multiple sources could prove helpful.

TC: What are the most distinctive qualities of Cebuano films that you can define and enumerate? Or, put in another way, what makes Cebuano films Cebuano?

MBA: The Cebuano language, first and foremost. Local stories told by local directors. I'm about to say something purely subjective, but I get the impression that with the bulk of Cebuano films made during my period of study (the early 1970s), there was very little desire to mimic mainstream Hollywood genre, as you might see in Tagalog cinema. There were exceptions of course, like Korak, a Tarzan film, directed by Alex Sunga, or Enter Garote, a martial arts movie, directed by Sol Gaudite. But a large number of the films were based on local popular culture: 
radio serials and comics. For the cultural warriors that stuck their neck out to make Cebuano films, there was a willingness to go all-out in the form of mixing up genre elements to gain audience attention. Batul of Mactan, for instance, was advertised as "Fantasy, Comedy, Action, Thrills Galore." The poster child for this genre-mash is, of course, Ang Manok ni San Pedro from 1977. It was first and foremost a comedy, but with lots of action, romance, fantasy, and melodrama. The pace is fast and the jokes, rapid-fire.

PDG: This question is one that comes up consistently. I think sometimes we answer in a knee-jerk fashion saying that the humor is particularly Cebuano, or the films drew from Cebuano cultural heritage. But I suspect that this is also a kind of fantasy that we create, and in some sense we may need to look at the way that Cebuano cinema is like many world cinemas. But when we look historically, it's so difficult because we don't have the films. Based on the anecdotal descriptions we get from the periodicals, we can see that, generically, the first big wave in film production through the 1950 s was predominantly melodrama. There were some adventure films as well and even some supernatural films such as the often-cited Mutya sa Saging Tindok, but even with the fantastical elements it seems that even Mutya is melodrama at its base. One of the reasons for this may well be that (and this again goes to the question of "Cebuano-ness") many of the early projects were helmed by Tagalogs and were therefore bringing the influence of the dominant national cinema to these films. If it is already difficult to untangle what is Filipino in Philippine national cinema, it is all the more difficult to get into these more minor entanglements of vernacular cinemas.

The next wave from the end of the 1960s through the 1970s saw the proliferation of more genre films. So starting with Badlis sa Kinabuhi, even if it is melodramas at its base, clearly the lessons of Italian NeoRealism and the work of Lamberto Avellana had affected the director's approach to filming. But there were martial arts films, fantasy films, westerns and comedies. Again we are still faced with the Tagalog influence, but personally, even if I am still suspicious about it as a kind of key to defining what is Cebuano in this local cinema, I guess the comedy is where we can locate a strong sense of Cebuano-ness. There was a great article that came out towards the end of the 1970s boom in Cebuano production entitled Lahi ang mga Sugboanaon nga Motan-aw sa Sine where it described how the Cebuano audience loved comedy, and at that moment, really for the first time, comedy was dominating Cebuano cinema. A lot of films with Yoyoy Villame were being made, 
movies like Wa Sa Ta Ron or Itlog, Manoy, Orange and, of course, Ang Manok ni San Pedro. And these films appeared to be doing really well at the box office in Cebu. Manok is still reputed to be the highest grossing Cebuano film (in large part to due to it's ingenious production methods) and yet it was also one of the last films produced prior to this long slump until the digital era. It is mysterious. In any case, the swiftness and materiality of the language when put to comedic ends so far strikes me as the most local element. It is certainly a big part of the recent film, Miss Bulalacao, and I think it is what people are responding to in that film. But again, is that enough to make a Cebuano film Cebuano? For me the jury is still out.

TC: In the case of Cebuano full-length films made in the last ten years, what qualitative difference can you distinguish between them and full-length films made by Manila-based filmmakers whose lingua franca is usually in Tagalog?

PDG: If it was difficult to unwrap Filipino and Cebuano films in the classical age of cinema production and exhibition, it is all the more difficult now. The influence of the past seemed to be simplistically twofold. That is, it was difficult to extricate the influence of Tagalog films (because of both talent and capital) and Hollywood films (because of the massive exposure of those films in the Philippines in general). In the last ten years, we have had to contend with an even more mongrel beast in which the influences are so fast, furious and continually mutating. From Korean soap operas, to YouTube phenomena, as well as the exposure to, for lack of a better term, global auteurs. With all of this, how do we go in and figure out what is distinctly Cebuano about a film? It is a question that has to be dealt with by academics and film critics if we want to articulate with any seriousness the concept of regional cinemas. However, having said that, I think that one thing that persists that seems to maintain some fidelity to a historical Cebuano sensibility is humor. From the plays of Piux Kabahar, through the songs of Yoyoy Villame and Max Surban, up to Miss Bulalacao, there is a lightning fast wit that seems to have something distinctly Cebuano about it. And this humor is something that resonates with the audiences when watching Cebuano movies, whether it's Ang Manok ni San Pedro or a film by Ara Chawdhury or Keith Deligero.

MBA: I remember a conversation I had with Ramon Bautista at the first official 2011 Binisaya Film Festival, we hosted at the University of San Carlos. He came to Cebu for a panel discussion, and outside the theatre we talked about the recently released Cebuano comedy, My Paranormal 
Romance, directed by an alumni, Victor Villanueva. He told me that he loved the film and that "a Tagalog couldn't have made that film, only a Cebuano," and he laughed. There is something about the peculiar local humor, vernacular references, goofy situations, and the Cebuano's visceral desire to just laugh — at anything — that rubs off into the films when it comes to comedy. I've questioned my wife, who is a Cebuana, about this, and she says, yes, there is a quality that only a local can relate to. The other thing is a kind of reluctance of local directors to make "poverty porn," and focus more on local issues surrounding provincial poverty and the challenges individuals have with maintaining personal morals, faith, and sacrifice for family. Films like Kordero sa Dios, directed by Keith Deligero, and Ang Damgo ni Eleuteria, directed by Remton Zuasola, come to mind-both University of San Carlos alumni, I might add!

TC: In doing research on a "lost" cinema, which profession would you liken to what you were doing in trying to attempt a history of Cebuano films-an investigative reporter interviewing people, a trial lawyer looking for evidence, or a paleontologist examining ancient clues?

MBA: All of the above! But seriously, I relate most to a paleontologist or anthropologist, if for no other reason, that the rewards are few, the effort is great, and one is breaking new ground. It's fascinating, and we here are very fortunate to have a University that supports research, and our research-based Masters of Arts Cinema Studies program. We just need a larger army to enroll in our graduate program, so that we can focus further on researching regional cinemas. Manila scholars have their hands more than full with Tagalog Cinema studies, but that is only one part of the fascinating puzzle that is Filipino Cinema.

PDG: A platypus composed of all the above, because I think that Cebuano cinema is often like a platypus. In a sense it is like trying to do ancient history, where none of the players are alive and all one is left with is the paper trail that needs to be pieced together. And of course, in synthesizing it, we have to get it wrong. Obviously, history is too messy for a couple of Westerners to come into a Cebuano archive and neatly put the pieces together. That's why parts of the book read more like an annotated filmography, where we just try and figure out what actually existed. So I guess it's also like being a lawyer trying to defend a case that $\mathrm{s} /$ he is not entirely sure of the guilt or innocence of the client but tries to make the best case possible with the evidence available. 


\section{Note}

1 So-called as a tribute to the late film critics Alexis Tioseco and Nika Bohinc, who were brutally slain in Tioseco's Quezon City home in September 2009.

TEDDY CO has been a curator and archivist for more than thirty years, organizing various film programs and retrospectives. He was instrumental in the recovery and repatriation of the "lost films" of Gerardo de Leon, Manuel Conde, and Nonoy Marcelo, among others. He is a constant member of the selection committees of Cinema One Originals, Quezon City International Film Festival, and Cinemalaya short films section. He co-founded and continues to curate Cinema Rehiyon, the biggest gathering of filmmakers from all around the Philippines. He is currently the Commissioner of the Arts of the National Commission for Culture and the Arts (NCCA) and the Chair of NCCA's Cinema Committee (corresponding author: maybayag@gmail.com). 